\title{
SALUTE TO SOME NURSING PIONEERS
}

P. H. Harrison, Head, Department of Nursing, University of Cape Town

\section{OPSOMMING}

'n Oorsig van sommige van die voortreflike verpleegpersoonlikhede wat 'n betekenisvolle bydrae tot die verpleegberoep in Suid-Afrika gelewer het. Dit begin in die dae van die Nederlandse Oos-Indiese Kompanjie se regering aan die Kaap tot vandag toe. Daar word verwys na baanbrekerswerk op die gebied van verloskunde, psigiatrie- en algemene verpleging, verpleegonderwys en professionele ontwikkeling. Daar word ook kommentaar gelewer oor Swart en Kleurlingbaanbrekersverpleegsters en die bydrae van sendingverpleegsters.

PIONEER - One who goes before to prepare the way; one who begins some enterprise, course of action; an original investigator; an initiator (Shorter Oxford English Dictionary).

$\mathbf{T}$ HIS is indeed a very wide meaning for the word, 'Pioneer', and it was with some trepidation that I approached this subject. After all, it could end up by being a sort of Biographical Directory of Nurses in South Africa and this is certainly not what our readers would like in this particular journal. In any case, Searle's History of the Development of Nursing in South Africa covers this field very fully and adequately.

So just what sort of people do we regard as pioneers of nursing in our country? Where do we begin? Can one be totally objective about it or would my choice be different from that of readers because of a more subjective attitude.

The word 'pioneer' conjures up in my mind, and in the context of South Africa, a picture of a vast, unexplored land at times cruelly hot and at other times cripplingly cold, teeming with wild life, African tribes (some friendly, some not so friendly), flooded rivers, ranges of mountains with no access roads or passes, malarialinfested in parts, isolated by vast distances from the comforts and security of civilisation. Into this panorama of splendid beauty and unknown dangers, puny man and his family treks onwards, deeper and deeper into the unknown. What he needs for survival he has to improvise. There is no going back for forgotten necessities or replenishment of used-up stores.

Pioneer women must have been hard-pressed to deal with the numerous health problems, such as births, hunting injuries, diseases, wounds from battles, burns, malnutrition, just to mention a few more obvious health hazards. No doctors, just women with handed-down skills which every female was expected to know.

\section{ORIGINS OF OUR NURSING TRADITIONS}

So let's travel back in history to the origins of our nursing traditions in our country. Perhaps the first pioneers in nursing were those women who helped at the birth of the first child to be born of the wife of a Dutch East India Company official - among them the Sick Comforter Wijlants - two months after Van Riebeeck landed.

These women had to care for all forms of illness, of course, and it is not difficult to imagine the difficulties with which they had to contend. Primitive shelters, hostile environment, inadequate medical supplies, factors requiring heroic efforts to maintain life. But they did and the tiny little community at the tip of Africa slowly started to flourish. This ability of the womenfolk to handle all sorts of health needs and to give supportive 
care to the sick laid the foundations of 'folk nursing' which was to be a feature of the rural areas for many years to come.

Special mention should be made of the midwifery traditions laid down during the almost 150 years of Dutch East India Company rule. The practice was to employ 'sworn midwives' for the community, in other words a sort of licence to practise. No illiterate, slovenly sick-attendant for this most vital aspect of community health. The midwife had a definite social status which implied responsibility and ethical conduct. Marie Buisset (who died in 1761) was one of the outstanding midwives of these early days. She had carried out a postmortem on the body of a female slave, and her report was accepted by the court which gives one an indication of the education and efficiency implied in the midwife's profession, even in those long-ago days.

As good midwifery is the basis of any health service, I would like to dwell, for a moment, on the founder of modern midwifery in our country, namely Mary Hirst Watkins.

This remarkable woman qualified first as a general nurse in Kimberley Hospital in 1887. She became a member of the British Nurses' Association in 1890 as a trained nurse. This qualification was recognised by the Colonial Medical Council and she was admitted to the Register for Trained Nurses in 1892. (The Cape Parliament had the previous year, 1891, passed the Medical and Pharmacy Act No. 34 which amongst other things, provided for the registration of nurses and midwives). Miss Watkins was thus one of the first registered nurses in the world.

Sister Henrietta Stockdale assigned Miss Watkins to district midwifery duties and the local doctors and Sister Henrietta supervised her midwifery training. She passed the Colonial Medical Council's midwifery examination the following year. Sister Henrietta then appointed her to be in charge of midwifery training in Kimberley and through her personal dedication and inspiration, generations of midwives were trained to give the highest standard of care in maternity and child welfare, not only in Kimberley but throughout Southern Africa, truly, one of South Africa's 'greats'. Since then, there has been a constant stream of distinguished midwives, each bringing her unique qualities to her students, enriching the total knowledge of the discipline of midwifery. One such midwife is Miss D. Copcutt. Under her guidance and initiative, midwifery training, especially at S.A. Nursing Council level (of which Miss Copcutt was a member), made great progress.

Other midwives, Miss R. Foxton of the Booth Memorial Home (Salvation Army) and Miss L. O. Agg (Supervisor of Midwives at the Cape Town City Council), broke new ground by organising the first Midwives' Refresher Course at the University of Cape Town and the first Midwives' Discussion Group of the South African Nursing Association (Western Province Branch) in 1949.

Now let's look at the area of psychiatric nursing. This particular field of nursing had always been regarded as the Cinderella of the profession. One must not forget, however, that custodial care was, until comparatively recently, the only treatment given to mental patients. The nursing personnel conformed to the standard pat- tern of medical treatment. Sometimes this care was compassionate, sometimes harsh - but initiative was not encouraged. By the very nature of the disorders, laws and regulations controlled the handling of these unfortunate patients. As the pharmaceutical science advanced, so the care of the mentally ill improved and a pioneer in this area is undoubtedly Miss Iris Marwick.

Under Miss Marwick's leadership and as a result of her vision the South African Nursing Council, in the early fifties, prescribed the one-year post-basic course leading to the certificate in psychiatric and neurological nursing. Against much opposition and in the face of enormous prejudice, Miss Marwick put psychiatric nursing on the map. As a result more and more general nurses take the psychiatric course and the Council also has an integrated basic course of general nursing with midwifery and/or psychiatric nursing thus, at long last, enabling nurses to give total care to their community. A new generation of psychiatric nurses has emerged and it is amongst the present practitioners that psychiatric nursing will be advanced to its full potential in the last twenty years of this century.

Miss Iris Röseher (a student of Miss I. Marwick), the newly elected President of the Nursing Council and the Chief Nursing Officer in the Department of Health has, with her team of assistants, the awesome task of initiating new ideas and preparing the way for even better psychiatric care.

Lastly - general nursing, who are our pioneers in this field? One thinks of those early days when the 'general' nurse was a multi-disciplinary person, before specialising had become a feature of the profession. District nurse, health visitor, operating theatre nurse, ward sister, matron, private duty nurse, nurse teacher - all had general nursing as the common denominator. Nurses who made particular contributions of a pioneering nature in these varied fields and performed their duties on the basis of that general nurse training plus that other indefinable attribute - faith in what they were doing, profound dedication, imagination and unbounded enthusiasm - are too numerous to mention and therefore, as I said at the beginning of this article, my choice must tend to be $s$ ubjective. If I have omitted to mention names that the reader would expect to see, I crave their indulgence.

One often wonders whether our generation of nurses is aware of or appreciates the heroic efforts of those women who belonged to the Anglican and Catholic Sisterhoods, or the missionary nurses of other denominations, who brought nursing based on Christian principles to lonely outposts and far-distant mission stations. Invariably women of genteel background and from civilised surroundings, they were ill-equipped to cope with the awesome demands of a hostile environment. But somehow these unsung pioneers of our profession, by the grace of God, tended the sick, counteracted witchcraft, overcame incredible obstacles and laid the foundations for the future concept of a comprehensive health service. Their example of dedication and concern influenced for good all those who came in contact with them. We salute these women and remember with gratitude their heroic sacrifices from which future generations of South Africans of all races have benefited. 
Bantu nursing - begun so tentatively in the 1870's by Dr. John Fitzgerald and Mrs. Ellen Parsons in Kingwilliamstown but with total conviction in the need for the Xhosa people to have nurses from their own cultural background, eventually resulted in Cecilia Makiwane becoming the first Black woman to qualify as a registered professional nurse in 1908. This was indeed a breakthrough for the Black women of South Africa and it is understandable that they look on this unique woman as their pioneer, who proved they had the ability and intelligence for professional training.

The formal training of Coloured midwives began in 1917 at St. Monica's Hospital, Cape Town. The pioneer Coloured midwife was Georgina Judson who was registered by the Colonial Medical Council in 1918. There was only one hospital in South Africa at this time where Coloured women could take their general training and this was at Lovedale.

Ella Ruth Gow (now Mrs. Gow-Kleinsmidt) first completed her general training in 1919 and then came to St. Monica's for her midwifery training which she completed in 1920, thus becoming the first Coloured general nurse and midwife. She too, proved to her own community, and the South African community at large, that given the opportunity, and in spite of certain prejudices and other obstacles, the Coloured woman was capable of achieving the highest standards of professional conduct and responsibility.

In the area of professional growth there are certain outstanding women who deserve our 'salute'. The first and obvious one, is Sister Henrietta Stockdale (died 1911). So much has been written about this great pioneer that I do not propose to repeat it here. Surely hers is a household name to all nurses in our country. But what was her unique contribution - this gentle, well-bred, devout woman, caught up in the hurly-burly, noisy, boisterous, materialistic clamour of the Diamond Fields? I suggest the reader refers to the appropriate chapters in Searle's History of Nursing in South Africa and Loots and Vermaak's Pioneers of Professional Nursing in South Africa for a full picture of Sister Henrietta. But mention must be made of her quiet determination through total conviction of the rightness of the matter, to educate her nurses so that they in turn became initiators for better and more effective care for their patients and thus spread outwards from Kimberley to all corners of Southern Africa the Sister Henrietta tradition.

Apart from her far-reaching influence on the education of nurses, Sister Henrietta was the pioneer par excellence in the establishment of nursing as a profession of acknowledged status through her active role in ensuring the nurse and midwife being included in the Medical and Pharmacy Act of 1891. This achievement led to the inevitable development of a professional organisation.

A procession of distinguished nurses now enters the stage, to lead nurses ever forward, commencing with Miss M. Nutt R.R.C., Matron of Somerset Hospital and first President of the South African Trained Nurses' Association, Miss B. G. Alexander R.R.C., Matron of the General Hospital, Johannesburg and first General Secretary of the South African Trained Nurses' Association. Miss Alexander worked indefatigably for full professional responsibility and laid the foundation for the later development of a South African Nursing
Council and Nursing Association given full independent existence by Act of Parliament.

Over the years crises of varying degrees have been experienced and on every occasion a nurse with special qualities has emerged to show the profession how to proceed.

Miss E. C. Lotz campaigned for the right of Afrikaansspeaking student nurses to be taught in their home language.

Miss C. M. Loopuyt was the first qualified tutor to give lectures in Afrikaans at the New Somerset Hospital.

Miss E. M. Pike, R.R.C., the first Matron of Groote Schuur Hospital, introduced the Block System of training in 1943, thus placing nursing education on a proper educational foundation.

Miss Sybil Marwick, active protagonist for nurses' rights at national and international level, who as President of the Trained Nurses' Association, led the profession during the Trade Union crisis and the years that followed until Parliament passed the first Nurses' Act of 1944.

Miss Jane McLarty, who played a major role in defusing a confrontation situation in 1942 when the profession was divided on the Trade Union controversy, and later became the Matron-in-Chief of the Baragwanath Hospital. Through her gifts of leadership and inspiration this Hospital, and Black South African nurses who trained there, were to become respected throughout Africa. As the first President of the newly-created South African Nursing Association, Miss McLarty laid sound foundations for a dvnamic professional organisation.

Miss M.G. Borcherds R.R.C., President of the South African Nursing Association (1953-1964), who, often alone and under stressful conditions, put South African nurses' point of view at many international meetings, with great dignity and calmness. A truly distinguished nurse.

Miss Connie Nothard R.R.C., who headed the South African Military Nursing Service during the Second World War 1939 - 1945, became first President of the newly-formed South African Nursing Council, guided this Council during its early formative years and remained at its helm until 1960.

So here we are, almost at the beginning of the last 20 years of the 20th century. Have we any pioneers or pioneer-material in our present ranks? Surely Professor Charlotte Searle is such a person. In the field of nursing education no other contemporary person has made or continues to make such strides forward. Studying the needs; doing research; writing; planning and executing new courses; initiating the nursing degree idea, bringing opportunities for advanced nursing studies within the reach of every nurse, no matter where she works, through the activities of her Department of the University of South Africa; negotiating at the highest level of Government in the area of socio-economic welfare of nurses. At times it is difficult to keep up with Professor Searle but with true pioneering determination and constancy of purpose, her objectives are invariably achieved.

I have no doubt that nurses in South Africa will continue to produce the pioneer spirit that will take the profession forward to the 21 st century - a profession equipped and ready for all the hazards and dangers of the uncharted seas that lie ahead. 